\title{
Phase Analysis of EN AW 6023 Aluminum Alloy after Short Time Aging
}

\author{
Miloš Matvija ${ }^{1}$, Martin Fujda ${ }^{1}$, Ondrej Milkovič ${ }^{1,2}$, Marek Vojtko $^{2}$, Miroslav Glogovský1 \\ ${ }^{1}$ Faculty of Materials, Metallurgy and Recycling, Technical University of Kosice. Letna 9, 04200 Kosice. Slovakia. \\ E-mail:milos.matvija@tuke.sk,martin.fujda@tuke.sk, ondrej.milkovic@tuke.sk, miroslav.glogovsky@tuke.sk \\ ${ }^{2}$ Institute of Materials Research, Slovak Academy of Science. Watsonova 47, 04001 Kosice. Slovakia. \\ E-mail: omilkovic@saske.sk, mvojtko@saske.sk
}

The phase analysis of the EN AW 6023 aluminum alloy after the heat treatment by short time aging was investigated. The good machinability of this heat treatable and lead free Al-Mg-Si wrought alloy is achieved by alloying of tin and bismuth. In experimental procedure, the solution annealing at $550{ }^{\circ} \mathrm{C}$ for 1 hour and subsequent water quenching of the analyzed alloy was realized. The short time artificial aging at $190{ }^{\circ} \mathrm{C}$ for 1 hour was carried out immediately after quenching. The microstructure analyses, the EDS analyses and the phase analyses using the hard X-ray diffraction by synchrotron radiation in DESY Hamburg were realized. Significant changes of the alloy phase composition were not observed after short time artificial aging applied on quenched and/or naturally aged alloy. Above all, the minority $\beta^{\prime \prime}\left(\mathrm{Mg}_{5} \mathrm{Si}_{6}\right)$ phase was identified as a strengthening phase in alloy $\alpha(\mathrm{Al})$ solid solution as the majority alloy phase. In addition, the minority of $\mathrm{Sn}, \mathrm{Mg}_{2} \mathrm{Sn}, \mathrm{Bi}_{2} \mathrm{Mg}_{3}, \mathrm{AlCu}_{2} \mathrm{Mn}, \mathrm{Al}_{15}\left(\mathrm{Mn}_{\text {, Fe }}\right)_{3} \mathrm{Si} \mathrm{i}_{2}$ phases were identified in alloy microstructure.

Keywords: Aluminum Alloy, Phase Analysis, Microstructure, Natural Aging, Artificial Aging

\section{Acknowledgement}

This work was supported by the Scientific Grand Agency of Slovak Republic as a grant project VEGA No. 1/0812/16. Parts of this research were carried out at PETRA III (beamline P02.1) at DESY, a member of the Helmholtz Association (HGF).

\section{References}

[1] TIMELLI, G., BOLOLLO, F. (2011). Influence of tin and bismuth on machinability of lead free 6000 series aluminiu alloys. In: Materials Science and Technology, Vol. 27, No. 1, pp. $291-299$.

[2] ARUGA, Y. (2015). Formation and reversion of clusters during natural aging and subsequent artificial aging in an Al-Mg-Si alloy. In: Materials Science and Engineering A, Vol. 631, pp. 86-96.

[3] FUJDA, M., MATVIJA, M., GLOGOVSKÝ, M., ORIŠENKO, I. (2017). Natural Aging Behaviour of the EN AW 6082 and Lead Free EN AW 6023 Aluminium Alloys. In: Manufacturing Technology, Vol. 17, No. 5, pp. 701 706.

[4] BANHART, J., et al. (2010). Natural ageing in Al-Mg-Si alloys - a process of unexpected complexity. In: $A d-$ vanced Engineering Materials, Vol. 12, pp. 559 - 571.

[5] JIA, Z., et al. (2016). Effects of high temperature pre-straining on natural aging and bake hardening response of Al-Mg-Si alloys. In: Transactions of Nonferrous Metals Society of China, Vol. 26, pp. 924 - 929.

[6] NOVOTNÝ, J., CAIS, J., NÁPRSTKOVÁ, N. (2014). Analysis of Aluminium Alloys AlSi7Mg0.3 and AlMg3 by Means of X-Ray Diffraction. In: Manufacturing Technology, Vol. 14, No. 3, pp. 392 - 397.

[7] DIPPEL, A.-C., LIERMANN, H.-P., DELITZ, J. T., WALTER, P., SCHULTE-SCHREPPING, H., SEECK, O., FRANZ, H. (2015). Beamline P02.1 at PETRA III for High-Resolution and High-Energy Powder Diffraction. In: Journal of Synchrotron Radiation, Vol. 22, No. 3, pp. 675 - 687.

[8] WERINOS, M., et al. (2016). Hardening of Al-Mg-Si alloys: Effect of trace elements and prolonged natural aging. In: Materials and Design, Vol. 107, pp. $257-268$.

[9] TIMELLI, G., et al. (2008). Proceedings of the 32nd AIM National Conference. Ferrara, Italy, University of Ferrara, Paper 126.

[10] REISO, O. (2004). Extrusion of AlMgSi alloys. In: Materials Forum, Vol. 28, pp. 32 - 46. 